\title{
HEAVY METAL CONTENT IN SOME SEAFOODS COLLECTED FROM MUARA ANGKE FISH AUCTION PLACE, JAKARTA.
}

\author{
by \\ HORAS P. HUTAGALUNG ${ }^{1)}$ and SUWIRMA SYAMSU ${ }^{2)}$
}

\begin{abstract}
Determination of heavy metal content ( $\mathrm{Hg}, \mathrm{Pb}, \mathrm{Cd}, \mathrm{Cu}, \mathrm{Cr}, \mathrm{Zn})$ in some seafoods collected from Muara Angke Fish Auction Place were carried out during February to July 1979. The results showed that Zn content in seafoods a nalyzed was always much higher than the other heavy metals. The concentration levels of the six heavy metals observed were low. It is almost of the same level as the metal concentration of other seafoods observed in various parts of the world oceans, but still lower than the maximum standard set for human consumption as established by Tasmania, Australia and World Health Organization. The mean per capita consumption of fish in Jakarta is only about $165 \mathrm{~g}$ per week, while the Provisional Tolerated Weekly Intake for $\mathrm{Hg}$, set by WHO/FAO at 300 ug level, would be attained by consuming 1500 g Rastrelliger sp., or 698 gPenaeus setiferus, or 545 g Sepia sp., and or $1250 \mathrm{~g}$ Pecten sp. Therefore, at present the level of metal content in fishes sold at TPI Muara Angke can be considered as not dangerous to human health as long as these quantities are not surpassed.
\end{abstract}

\section{ABSTRAK}

KANDUNGAN LOGAM BERAT DALAM BEBERAPA JENIS HASIL LAUT YANG DIKUMPULKAN DARI TEMP AT PELELANGAN IKAN MUARA ANGKE, JAKARTA. Penentuan kan-dungan logam berat ( $\mathrm{Hg}, \mathrm{Pb}, \mathrm{Cd}, \mathrm{Cu}, \mathrm{Cr}, \mathrm{Zn})$ dalam beberapa jenis hasil laut yang dijual di Tempat Pelelangan Ikan Muara Angke telah dilakukan dari bulan Februari sampai Juli 1979. Hasil-hasil ana-lisa menunjukkan bahwa kandungan $\mathrm{Zn}$ dalam hasil laut yang diamati selalu lebih tinggi dibanding-kan dengan kandungan logam berat lairmya. Kandungan ke enam logam berat yang diamati masih rendah dan hampir sama dengan kandungan logam berat dalam hasil-hasil laut yang berasal dari beberapa perairan dunia. Disamping itu juga lebih rendah dibandingkan dengan kadar maksimum logam berat dalam ikan laut untuk konsumsi manusia yang ditetapkan oleh Pemerintah Tasmania, Australia dan Organisasi Kesehatan Dunia. Konsumsi ikan penduduk Jakarta rata-rata adalah 165 g per kapita per minggu, dan jumlah maksimum Hg yang boleh masuk ke dalam tubuh manusia per minggu (Provisional Tolerated Weekly Intake=PTWI) menurut WHO/FAO adalah 300 ug. Nilai PTWI ini akan tercapai bila penduduk mengkonsumsi 1500 g ikan kembung, Rastrelliger sp. 698 g udang, Penaeus setiferus., 545 g cumi-cumi, Sepia Sp., atau 1250 g kerang, Pecten sp. Jumlah yang diperbolehkan ini jauh lebih banyak dibandingkan dengan jumlah rata-rata konsumsi ikan per kapita penduduk Jakarta. Oleh karena itu pemanfaatan hasil laut yang diamati dan dijual di TPI Muara Angke tidak akan membahayakan kesehatan asalkan jumlah yang dikonsumsi tidak melebihi jumlah yang diperbolehkan WHO/FAO tersebut.

1). Pusat Penelitian dan Pengembangan Oseanologi (Centre for Oceanological Research and Development) — LIPI, Jakarta, Indonesia.

2). Pusat Aplikasi Isotop dan Radiasi (Centre for the Application of Isotop and Radiation)-BATAN, Jakarta, Indonesia. 


\section{INTRODUCTION}

Fish and other marine organisms are some of the heavy metal pathways entering the human body. The amount of heavy metal enters the human body depends on the amount of fish consumed and the heavy metal content in the fish meat. On the other hand heavy metal content in fishes depends on heavy metal concentration in the environment. RAEDER \& SNEKVIK ( 1941 in BOUSH \& THIELEKE 1983b) reported that the mercury levels in both freshwater and marine fishes of contaminated areas were higher than those found in uncontaminated waters. In the early 1970s BousH \& THIELEKE (1983a) found that the pelagic species such as tuna, shark, swordfish and marlin have concentration of mercury exceeding the current provisional maximum permissible level of $1 \mathrm{mg} / \mathrm{kg}$ established by The United States Food And Drug Administration. The utilization of contaminated fish and shellfish would be hazardous to human health as was evident in cases of Minamata Disease in Japan between 1953-1964 (KuRTLAND et al 1960 in Boush \& THIELEKe 1983b). It has been reported that the Minamata Disease killed 46 peoples and seriously injured nearly 100 peoples after eating fish and shellfish contaminated with alkylmercury compound.

In Jakarta there are several Fish Auction Places (Tempat Pelelangan Ikan = TPI), one of which is the TPI Muara Angke which is also the biggest. Fish and other marine organismssold here come from Jakarta Bay and other Indonesian waters. Heavy metal concentration is moderately high in the Jakarta Bay water (YATIM et al. 1979), and generally low in the other Indonesian waters, such as Cilacap, Banten Bay, Sulawesi sea etc. (HUTAGALUNG \& HAMIDAH s.a.). Heavy metal content in some fishes caught at Angke Estuary, Jakarta Bay, has been reported by HUTAGALUNG \& RAZAK (1982), while that in fishes sold at TPI Muara Angke are almost unknown. As mentioned earlier heavy metal concentration in the other Indonesian waters is relatively low. However it is important to study the heavy metal content in fish and other marine organisms as a mean to protect the human health from heavy metal hazard.

\section{MATERIALS AND METHODS}

The samples of commercial seafoods were purchased from TPI Muara Angke. Sampling was done monthly during a six months period (February to July 1979). The specimens were then packed in polyethylene bags and brought directly to the laboratory for analysis. As stated earlier, the primary objective of this study is to determine the heavy metal content in those part of seafood which are usually consumed. Composite samples obtained by mixing homogenous specimen samples taken from individual sea food were analyzed for $\mathrm{Hg}, \mathrm{Pb}, \mathrm{Cd}, \mathrm{Cu}, \mathrm{Cr}$ and $\mathrm{Zn}$. Magnesium nitrate $\left(\mathrm{Mg}\left(\mathrm{NO}_{3}\right) 2\right)$ is added into homogenated composite samples which were then pyrolized at $500^{\circ} \mathrm{C}$ for two hours (ZOOK et al. 1976). After that the samples were further treated carefully with $1 \mathrm{ml}$ concentrated nitric acid and diluted with distilled water to a standard volume of $25 \mathrm{ml}$. Total $\mathrm{Pb}, \mathrm{Cd}, \mathrm{Cu}, \mathrm{Cr}$ and $\mathrm{Zn}$ contents were determined by ato- 


\section{HEAVY METAL CONTENTIN SOME SEAFOODS}

mic absorption spectrophotometer. For the determination of mercury, homogenated composite samples were digested in concentrated sulfuric acid, $6 \%$ potassium permanganate $\left(\mathrm{KMnO}_{4}\right)$ and heated for 12 hours at $60^{\circ} \mathrm{C}$. Following digestion, excess of oxydizing agents $\left(\mathrm{KMnO}_{4}\right)$ were reduced with sodium chloride-hydroxylaniine solution (LAMM \& RUZICKA 1972). Mercury ion $\left(\mathrm{Hg}^{2+}\right)$ were then reduced to elemental mercury $\left(\mathrm{Hg}^{\circ}\right)$ with stannous chloride. Total mercury contents of all samples were then determined by flameless atomic absorption spectrophotometer.

\section{RESULTS AND DISCUSSION}

Four commercial seafoods were studied (Table 1). The $\mathrm{Zn}$ contents in seafoods analyzed were always much higher than the concentration of $\mathrm{Hg}, \mathrm{Pb}, \mathrm{Cd}, \mathrm{Cu}$ and $\mathrm{Cr}$ (Fig. 1). It means that the organisms analyzed accumulate $\mathrm{Zn}$ more than $\mathrm{Hg}, \mathrm{Pb}, \mathrm{Cd}$, $\mathrm{Cu}$ and $\mathrm{Cr}$. In general $\mathrm{Zn}$ concentration in the sea water is higher than the other heavy metals. HUTAGALUNG \&HAMIDAH (s.a.) reported that the Indonesian sea waters have similar metal content characteristics. The high concentration of $\mathrm{Zn}$ in the marine organisms may be due to high concentration of $\mathrm{Zn}$ in sea water. Comparing the present study to those reported in the literatur, it can be seen that the result is similar to the results from the other regions such as Mediterranean coastal area, Israel, in March to September 1974 (ROTH \& HORNUNG 1977); St. Louis Bay, Mississippi, in December 1978 (LYTLE \& LYTLE 1982); Gdanks Bay, Poland, in October and November 1981 (Szefer \& Szefer 1985); Cockburn Sound, Australia (Plasket \& PotTer 1979); Philippine sea waters, in 1975-1977 (KAPAUn et al. 1979 in HUNGSPREUGS 1984); and Derwent Estuary, Tasmania, in November 1972-January 1973 (EusTACE 1974). Based on the findings reported here as well as on other studies mentioned above it can be concluded that regardless of the season, the $\mathrm{Zn}$ content in marine organisms is always higher than the other heavy metal contents.

In most of the marine organisms the $\mathrm{Cu}$ concentration is always higher than $\mathrm{Hg}$, $\mathrm{Pb}, \mathrm{Cd}$ and $\mathrm{Cr}$ contents (Table 3). This is also seen in seafood samples purchased at TPI Muara Angke, e.g. in Rastrettiger sp. the $\mathrm{Cu}$ content is 8.4 times higher compared to $\mathrm{Hg}$ and 25 times higher than $\mathrm{Cd}$ (Table 2). This mean that the intake capacity of $\mathrm{Cu}$ is more than $\mathrm{Hg}, \mathrm{Pb}, \mathrm{Cd}$ and Cr. LENINGER (1977 in MARKS et al 1980) reported that marine organisms need $\mathrm{Zn}$ and $\mathrm{Cu}$ for metabolism process as "metal cofactor" in "physiological metalloenzymes". It causes the intake capacity of $\mathrm{Zn}$ and $\mathrm{Cu}$ more than non-essential heavy metals i.e. $\mathrm{Hg}, \mathrm{Pb}$, Cd and $\mathrm{Cr}$. Differing with $\mathrm{Zn}, \mathrm{Cu}, \mathrm{Hg}, \mathrm{Pb}$ and $\mathrm{Cd}$, the concentration of $\mathrm{Cr}$ can not be determined because the limiting concentration of $\mathrm{Cr}$ to be detectable is $0.009 \mathrm{ppm}$. In Indenesian sea waters, the concentration of $\mathrm{Cr}$ is usually undetectable (HUTAGALUNG \& HAMIDAH s.a.).

In marine ecosystem the highest heavy metal content is always recorded in bivalve molluscs (Plasket \& PotTer 1979). In the biota caught at Angke Estuary, the highest $\mathrm{Pb}$ and $\mathrm{Cd}$ contents were also found in bivalve mollusc, Anadara antiquata (HUTAGALUNG \& RAZAK 1982). Samples taken from TPI Muara Angke revealed that the bivalve has the highest content of $\mathrm{Zn}$ and Cd only, while for other heavy metals 
the concentration seems to be more or less the same as in fishes, shrimps and squids. Therefore, it can be assumed that the samples studied came from different areas having different .water quality.

The results obtained from the meat analysis of Rastrelliger sp., Penaeus setiferus, Sepia sp., andPecten sp., purchased at TPI Muara Angke show that the concentration levels of the six heavy metals investigated are low and almost of the same value as for other fishes studied in various parts of the world oceans (Table 3). Therefore, it can be said that the seafoods sold at TPI Muara Angke are relatively uncontaminated by $\mathrm{Hg}$, $\mathrm{Pb}, \mathrm{Cd}, \mathrm{Cu}, \mathrm{Cr}$ and $\mathrm{Zn}$. The heavy metal contents in these seafoods are still in the natural normal range for heavy metal content in marine organisms. The Current 1971 State Food Standards Regulation in Tasmania specifies allowable maximal for concentration of $\mathrm{Zn}, \mathrm{Cu}$ and $\mathrm{Cr}$ in food to be $40 \mathrm{ppm}, 30 \mathrm{ppm}$, and $5.5 \mathrm{ppm}$, respectively (EUS TACE 1974). The maximum standard of $\mathrm{Hg}$ in fish for human consumption established by World Health Organization is 0.5 ppm (ENVIRONMENTAL PROTECTION AGENCY 1973), and The Australian National Health and Medical Research Council (NHMCR) decided that the maximum standard concentration of $\mathrm{Pb}$ and $\mathrm{Cd}$ is $2 \mathrm{ppm}$ each (PLASKET \& POTTER 1979). From a hygienic point of view it is clear that all the commercial seafoods analyzed showed lower $\mathrm{Hg}, \mathrm{Pb}, \mathrm{Cd}, \mathrm{Cu}, \mathrm{Cr}$ and $\mathrm{Zn}$ levels than the limit permitted by the Current 1971 State Food Standards Regulation in Tasmania, World Health Organization and NHMCR Standards (Table 1). The human health hazard by heavy metal toxicity depends on the concentration and the amount of heavy metal entering the human body. Because of the amount of heavy metal that enter the human body also depend on the amount of fish consumed, therefore WHO/FAO decided that the Provisional Tolerated Weekly Intake (PTWI) of the total mercury is 300 ug for a $70 \mathrm{~kg}$ body weight (MAHAFFEY et al. 1975). If the concentration of $\mathrm{Hg}$ in fish is known then the amount of fish which may be consumed can be calculated from the PTWI value i.e. 300 ug, divided by the concentration of $\mathrm{Hg}$. For example, the highest of Hg content in Rastrelliger sp. analyzed is $0.20 \mathrm{ppm}$. The PTWI of total mercury would be attained

by consuming $\frac{300 \mathrm{ug}}{0.2 \mathrm{ug} / \mathrm{g}}=1500 \mathrm{~g}$ fish. By the same calculation the PTWI of total mercury would be attained by consuming 698 g Penaeus setiferus, or 545 g Sepia sp., or $1250 \mathrm{~g}$ Pecten sp. Because of the mean per capita consumption of fish in Jakarta is only about 165 g per week (SoEsAnto \& TugAswati 1983), the present level of metals in seafoods sold at TPI Muara Angke can be considered as not dangerous to human health.

\section{REFERENCES}

BOUSH, G M and J. M. THIELEKE 1983a Mercury content in sharks. Bull. Environ. Contam. Toxicol SO: 284-290.

BOUSH, G. M and J. M THIELEKE 1983b Total mercury content in Yellowfin and Bigeye Tuna. Bull. Environ. Contam. Toxicol. 30: 291-297.

ENVIRONMENTAL PROTECTION AGENCY 1973 Water quality criteria. Ecological Research Series. Washington. 595 pgs.

EUSTACE, I.J. 1974 Zinc, cadmium, copper and manganese in species of finfish and shellfish caught in the Derwent Estuary, Tasmania. Aust. J. Mar. freshw. Res. 25: 209-220. 


\section{HEAVY METAL CONTENT IN SOME SEAFOODS}

HUNGSPREUGS, M 1985 Marine pollution by heavy metals in the East Asian Region. In "Environment and resources in the Pacific". UNEP Regional Seas Reports and Studies. 69: 239-248.

HUTAGALUNG, HORAS P. and H. RAZAK 1982 Pengamatan pendahuluan kadar Pb dan Cd dalam air dan biota di estuaria Muara Angke. Oseanol di Indonesia. 15: 1-10. (in Indonesian with english summary).

HUTAGALUNG, HORAS P. and HAMIDAH s.a. Kandungan logam berat dalam beberapa perairan laut Indonesia. Dalam "Kondisi lingkungan pesisir dan laut di Indonesia" (Romimoh-tarto \& Thayib eds.). Lembaga Oseanologi Nasional-Lembaga Ilmu Pengetahuan Indonesia, Jakarta.: 223-246.

INTERNATIONAL COUNCIL FOR THE EXPLORATION OF THE SEA 1984 Cooperative research report. The ICES coordinated monitoring programme for contaminants in fish and shellfish 1978 and 1979, and six year review of ICES coordinated monitoring programme. 126: 1-100.

LAMM, G. G and J. RUZICKA 1972 The determination of tracers of mercury by spectrophoto-metry, atomic absorption, radio isotop dilution and other methods. In "Mercury contamination in man and his environment" (Weinteringham edt.). Tech. Rep. Series. 137: 1-3.

LYTLE, T. F and J. S. LYTLE 1982 Heavy metals in oyster and clams of St. Louis Bay, Mississippi. Bull Environ. Contam. Toxicol 29: (1) : 50-57.

MAHAFFEY, K. R; P. E. CORNELLIUSSEN; C. F. JELINEK and J. A. FIORINO 1975 Heavy metal exposure from foods. Environ. Health Perspective. 12: 63-69.

MARKS, P. J.; D. PLASKET,; L C. POTTER and J. S. BRADLEY 1980. Relationship between concentration of heavy metals in muscle tissue and body weight of fish from the SwanA von estuary, Western Australia. Aust. J. Mar. freshw. Res. 31 : 783-793.

MIETTINEN, V and M. VERTA 1978 On the heavy metals and chlorinated hydrocarbon in the Gulf of Bothnia in Finland. Finfish Mar. Res. 244: 219-226.

PLASKET, D and I. C. POTTER 1979 Heavy metal concentration in the muscle tissue of 12 species of teleost from Cockburn Sound, Western Australia. Aust. J. Mar. Freshw. Res. 30: 607-616.

ROTH, I. and H. HORNUNG 1977 Heavy metal concentration in water, sediments, and fish from Mediterranean coastal area, Israel. Israel Oceano. Limno. Res. 11 (3) : 168-172.

SOESANTO, S. S and T. TUGASWATI 1983 Teluk Jakarta belum tercemar racun mercury. In Harian Sinar Harapan", 4-10-1983 (in Indonesian).

SZEFER, P. and IC SZEFER 1985 Occurence of ten metals in Mytilus edulis L. and Cardium glau-cum L. from the Gdanks Bay. Afar. Pollut. Bull. 16 (11) : 446-450.

YATIM, S.; S. SURTIPANTI; S. SUwIRMA and E. LUBIS 1979 Distribusi logam berat dalam air permukaan Teluk Jakarta. Majalah Batan. XIII (3) : 1-19.

Zook, E. P.; J. J. Powell; B. M. Hackley,; J. A. Emerson,; J. R Brooker and G. M. KNOBL, Jr. 1976 National Marine Fisheries Services preliminary survey of selected sea food for mercury, lead, cadmium and arsenic content. J. Agric. Food Chem. 24 : 47-56. 


\section{HutAgALUng \& S. SyAmSU}

Table 1. Range, $X \pm S . D(n=21)$ of heavy metal content (ppm, wet weight) in seafoods bought from TPI Muara Angke.

\begin{tabular}{|c|c|c|c|c|c|c|}
\hline & $\mathrm{Hg}$ & $\mathrm{Pb}$ & $\mathrm{Cd}$ & $\mathrm{Cu}$ & $\mathrm{Cr}$ & $\mathrm{Zn}$ \\
\hline \multirow[t]{2}{*}{ Fish, Rastrelliger sp } & $0.02-0.20$ & $0.17-0.67$ & $0.02-0.03$ & $0.50-1.07$ & u.d & $4,36-10.71$ \\
\hline & $0.09 \pm 0.07$ & $0.45 \pm 0.19$ & $0.03-0.01$ & $0.76 \pm 0.18$ & - & $7.69 \pm 1.69$ \\
\hline \multicolumn{7}{|c|}{ shrimps, Penaeus setiferus } \\
\hline & $0.05-0.43$ & u.d & $0.02-0.04$ & $0.60-3.17$ & u.d & $9.91-14.01$ \\
\hline & $0.13 \pm 0.14$ & - & $0.02 \pm 0.01$ & $2.09+0.86$ & - & $12.09 \pm 1.69$ \\
\hline \multirow[t]{2}{*}{ squid, Sepia sp. } & $0.03-0.55$ & u.d & $0.01-0.03$ & $0.50-1.66$ & u.d & $7.25-13.88$ \\
\hline & $0.18 \pm 0.18$ & - & $0.02 \pm 0.01$ & $1.14 \pm 0.46$ & - & $11.15 \pm 2.29$ \\
\hline \multirow[t]{2}{*}{ scallop, Pecten sp. } & $0.02-0.24$ & u.d & $0.02-0.22$ & $0.64-1.66$ & u.d & $8.93-18.00$ \\
\hline & $0.10 \pm 0.07$ & - & $0.07 \pm 0.07$ & $1.08 \pm 0.39$ & - & $15.51 \pm 3.20$ \\
\hline \multicolumn{2}{|c|}{$\begin{array}{l}\text { - recommended maximum } 0.5^{\mathrm{a}} \\
\text { concentration, } \mathrm{ppm}\end{array}$} & $2^{b}$ & $2^{b}$ & $30^{c}$ & $5.5^{\mathrm{c}}$ & $40^{c}$ \\
\hline
\end{tabular}

notes: * maximum concentration in fish for human consumption.

a. by World Health Organization (in Environmental Protection Agency 1973).

b. by Australian National Health and Medical Research Council (in Plasket \& Potter 1979).

c. by Tasmanian Food and Drug Regulation 1971 (in Eustace 1974).

u.d. undetectable.

Table 2. Ratio of Cu content to other heavy metals content in each sample collected from TPI Muara Angke.

\begin{tabular}{lcccc}
\hline & $\mathrm{Hg}$ & $\mathrm{Pb}$ & $\mathrm{Cd}$ & $\mathrm{Cr}$ \\
\hline fish, Rastrelliger sp. & 8.4 & 1.7 & 25 & 84 \\
shrimp, Penaeus setiferus & 16.1 & 261 & 105 & 232 \\
squid, Sepia sp. & 6.3 & 143 & 57 & 127 \\
scallop, Pecten sp. & 10.8 & 135 & 15 & 120 \\
\hline
\end{tabular}


HEAVY METAL CONTENT IN SOME SEAFOODS

Table 3. Heavy metal content (ppm, wet weight) in seafoods collected at TPI Muara Angke and other areas.

\begin{tabular}{|c|c|c|c|c|c|c|c|}
\hline Location & $\mathrm{Hg}$ & $\mathrm{Pb}$ & $\mathrm{Cd}$ & $\mathrm{Cu}$ & $\mathrm{Cr}$ & $\mathrm{Zn}$ & References \\
\hline fish, present study & $0.02-0.20$ & $0.17-0.67$ & $0.02-0.03$ & $0.50-1.07$ & u.d & $4.36-10.7$ & \\
\hline Norway & $0.00-0.96$ & & & $0.02-0.79$ & & $2.60-7.7$ & I.C.E.S. (1984). \\
\hline Canada & $0.02-0.12$ & $0.07-0.68$ & $0.00-0.04$ & $0.24-1.63$ & & $3.50-6.4$ & I.C.E.S. (1984). \\
\hline Belgium & $0.04-0.71$ & $0.15-0.57$ & $0.01-0.02$ & $0.20-1.31$ & $0.10-0.70$ & $3.40-8.8$ & I.C.E.S. (1984). \\
\hline Ireland & $0.04-0.51$ & $0.01-0.15$ & $0.00-0.08$ & $0.10-0.35$ & & $1.87-4.5$ & I.C.E.S. (1984). \\
\hline France & $0.01-0.23$ & $0.01-0.15$ & $0.00-0.03$ & $0.06-0.51$ & & $3.20-10.6$ & I.C.E.S. (1984). \\
\hline Philippine & & $0.00-0.45$ & $0.00-0.13$ & $0.21-9.93$ & & $2.59-42.3$ & $\begin{array}{l}\text { Kapaun et al. } \\
(1979 \text { in Hungs- } \\
\text { preugs 1985). }\end{array}$ \\
\hline $\begin{array}{l}\text { Mediterranean coastal, } \\
\text { Israel }\end{array}$ & & $0.01-1.30$ & $0.02-0.17$ & $0.17-2.00$ & $0.14-1.20$ & $0.10-20.3$ & $\begin{array}{l}\text { Roth \& Hornung } \\
\text { (1977). }\end{array}$ \\
\hline Scottish waters & & $0.20-1.20$ & $0.03-0.12$ & $0.05-4.30$ & & $1.60-23.0$ & $\begin{array}{l}\text { Topping (1973in } \\
\text { Roth \& Hornung } \\
\text { (1977). }\end{array}$ \\
\hline England and Wales & & $0.50-1.00$ & $0.05-0.16$ & $0.50-1.80$ & $0.50-0.60$ & $4.40-6.6$ & $\begin{array}{l}\text { Portman (1972in } \\
\text { Roth \& Hornung } \\
\text { 1977). }\end{array}$ \\
\hline New Zealand & & $0.04-1.60$ & $0.00-0.20$ & $0.03-3.40$ & $0.01-0.05$ & $0.90-56.0$ & $\begin{array}{l}\text { Broeks et al. } \\
\text { (1974 in Roth \& } \\
\text { Hornung 1977). }\end{array}$ \\
\hline Gulf of Bothnia Finland & $0.02-0.63$ & $0.03-0.25$ & $0.00-0.04$ & $0.19-1.10$ & & $3.50-19.0$ & $\begin{array}{l}\text { Miettinen \& Ver- } \\
\text { ta (1978). }\end{array}$ \\
\hline $\begin{array}{l}\text { Cockburn Sound } \\
\text { Australia }\end{array}$ & & $0.35-1.24$ & $0.04-0.08$ & $0.17-1.38$ & $0.05-0.18$ & $4.00-21.6$ & $\begin{array}{l}\text { Plasket \& Potter } \\
\text { (1979). }\end{array}$ \\
\hline $\begin{array}{l}\text { Shelifish, present } \\
\text { study }\end{array}$ & $0.02-0.24$ & u.d & $0.02-0.22$ & $0.64-1.66$ & u.d & $8.93-18.0$ & \\
\hline England/Wales & $0.04-0.12$ & $0.70-4.30$ & $0.20-2.00$ & $1.00-2.50$ & & $15.00-62.0$ & I.C.E.S (1984). \\
\hline Bolgium & $0.06-0.19$ & $0.28-0.88$ & $0.02-0.06$ & $11.70-19.30$ & $0.10-0.77$ & $25.60-82.8$ & I.C.E.S (1984). \\
\hline Philippine & & $0.02-0.24$ & $0.00-0.27$ & $1.86-5.00$ & & $10.40-53.9$ & $\begin{array}{l}\text { Hungspreugs } \\
\text { (1985). }\end{array}$ \\
\hline Finland & $0.00-0.13$ & $0.30-1.50$ & $0.20-0.80$ & $5.00-56.00$ & & $14.00-99.0$ & $\begin{array}{l}\text { Miettinen \& } \\
\text { Verta (1978). }\end{array}$ \\
\hline
\end{tabular}

Notes : I.C.E.S. = International Council for the Exploration of the Sea.

u.d = undetectable. 


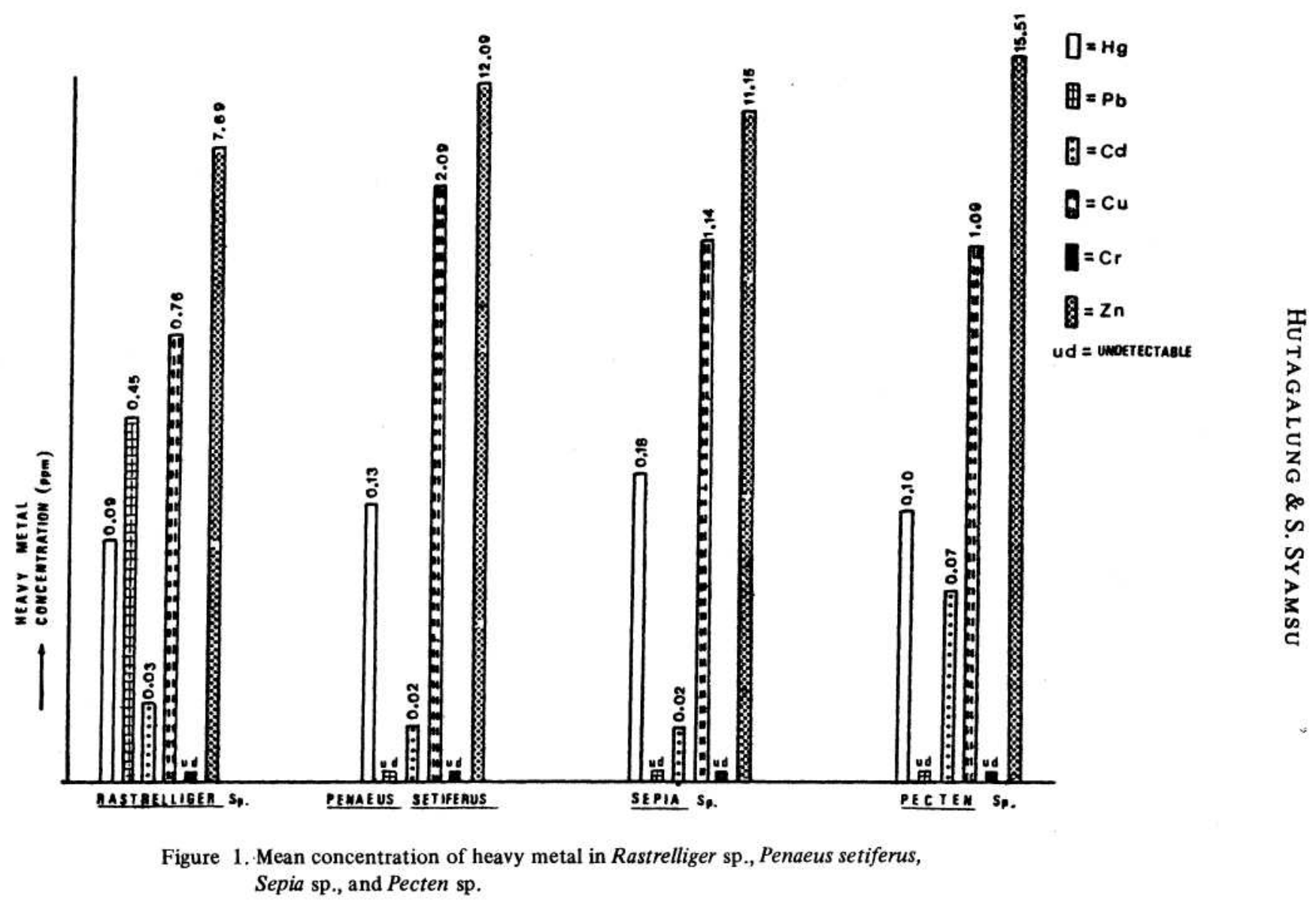

